\title{
UTILIZATION OF ADC PIN ON ARDUINO NANO TO MEASURE VOLTAGE OF A BATTERY
}

\author{
Muh Pauzan ${ }^{1^{*}}$, Indri Yanti ${ }^{1}$ \\ ${ }^{1}$ Department of Computer Engineering, Universitas Wiralodra, Indonesia
}

\section{A R T I C LE INF O \\ History of the article:}

Received November 15, 2021

Revised December 18, 2021

Accepted December 21, 2021

Published December 26, 2021

\section{Keywords:}

Battery

Voltage level

Arduino

ADC

Microcontroller

\begin{abstract}
Batteries are DC sources, several range of voltages and dimensions are found on the market, some are $1.5 \mathrm{~V}, 3.7 \mathrm{~V}$ and $9 \mathrm{~V}$ with various dimension such as AAA, AA and PP3. Voltage is an important aspect in a battery, the voltage could be measured using a multimeter and a specific voltagemeter device for battery. The latter device cannot be used to measure voltages in various dimensions and voltage of batteries. According to the problem, a battery voltage-meter is made for all types of batteries with a voltage rating ranging from $0-10 \mathrm{~V}$. The device could replace the current voltage-indicator device for battery. Arduino nano is employed as controller and a LCD is used to display the voltage. The analog to digital converter pin on Arduino is used to read the voltage, voltage source is an analog signal. The signal is converted by the microcontroller into a digital one. The digital signal is processed by microcontroller and the result is shown on LCD. Due to the device is designed to measure a maximum $10 \mathrm{~V}$ battery, a voltage divider circuit is employed. The microcontroller could accept $5 \mathrm{~V}$. The resistors used in the voltage divider circuit are the $4.7 \mathrm{k} \Omega$ and the $10 \mathrm{k} \Omega$ series arrangement. Based on voltage indicator test, the device has a better accuracy when using $10 \mathrm{k} \Omega$ resistor compared to $4,7 \mathrm{k} \Omega$. It displays voltage value up to two digit after the comma. Our device solves limitation of the current device in market which is just to be able check a specific type of battery.
\end{abstract}

\section{Correspondece:}

Muh Pauzan,

Department of Computer Engineering,

Universitas Wiralodra, Indonesia,

Email : muhpauzan.ft@unwir.ac.id
This is an open access article under the CC BY-ND license.

\section{INTRODUCTION}

Batteries are DC (direct current) source, the battery has a variety of voltages, namely $1.5 \mathrm{~V}, 3.7 \mathrm{~V}$ and $9 \mathrm{~V}$. Besides various dimensions found on the market such as AAA, AA and PP3. In general, batteries are divided into two parts: non-rechargeable and rechargeable batteries. Batteries that cannot be charged are usually made of zinc-carbon or alkaline, while rechargeable batteries are made of lithium-ion (Li-lon). Batteries on the market are usually nonrechargeable, while chargeable batteries are limited in stores because these types of batteries are usually used for electronics projects. Currently, research on voltage indicator of batteries is limited to a certain types of batteries. In previous research, an indicator of voltage level on $12 \mathrm{~V}$ battery has been made using the BC547 transistor, this device is specifically designed to determine the voltage on the motor accumulator [1]. Voltage indicator of series arrangement of two li-ion 18650 batteries have been made and LEDs are used as voltage's indicator. An operational amplifier (opamp) is employed as comparator. If the glow is blue the voltage is full, a green one means the battery voltage between $26-75 \%$ and a red glow means the voltage of the batteries below $25 \%$. However, the device made by [2] cannot be used to measure the voltage on other type of batteries. Other research by [3], a voltage monitoring system was created on four Li-ion batteries arranged in series, aim of the research is to measure the voltage of each battery arranged in series. A monitoring system for battery (cell) voltage is made by means of LC series circuit, the result shows that the method could estimate each battery voltage with high accuracy[4]. [5] Made a digital power supply by utilizing ADC (analog to digital converter) pin on the microcontroller ATmega8535. ADC pins in microcontroller are employed to establish realistic loading and transient effects on calibration[6], to generate signal pattern [7], for power management system[8], to design low cost control system [9], to measure battery 
management system [10], and for acquisition voltage and current of alternating current (AC) source [11]. Other research about battery are battery management system (BMS) for photovoltaic (PV) by means of microcontroller [12], mobile application for BMS with IOT (Internet of Things) platform [13].

Based on the previous researches, device to measure the battery's voltage is just for a certain type and dimensions of battery. It could not measure the voltage of every voltage's rating and dimension of battery. Utilization of ADC pins in other research that is mentions above are not to measure the voltage of a battery. Therefore, to give solution of these problems, a simple device would be made to measure the battery's voltage for various dimensions and voltage's rating of batteries. The Arduino nano board is used as a battery voltage reader, microcontroller ATmega328p on the Arduino has an ADC (analog to digital converter) feature [14]. ADC is a facility to convert analog voltage, like [5] did to make a digital power supply. Analog voltage could come from sensors, batteries, and others. So that any analog signal can be converted to digital form. Arduino-based device is designed to measure battery voltage in the range $0-10 \mathrm{~V}$. Due to the device is designed to measure a maximum $10 \mathrm{~V}$ battery, a voltage divider circuit is employed. The microcontroller could accept $5 \mathrm{~V}$, if $10 \mathrm{~V}$ is given directly to the analog pin it will damage the Arduino board. Contribution of our work is that utilization of ADC pins could be used to convert any value of DC voltage source by means of voltage divider circuits.

\section{RESEARCH METHOD}

Arduino-based device for battery-voltage meter starts from determining how the device works, then the hardware design, software design and the last is device testing. The explanation of each step is as follows:

\section{Working Principle of the Device}

The schematics works of the device could be seen in Figure 1:

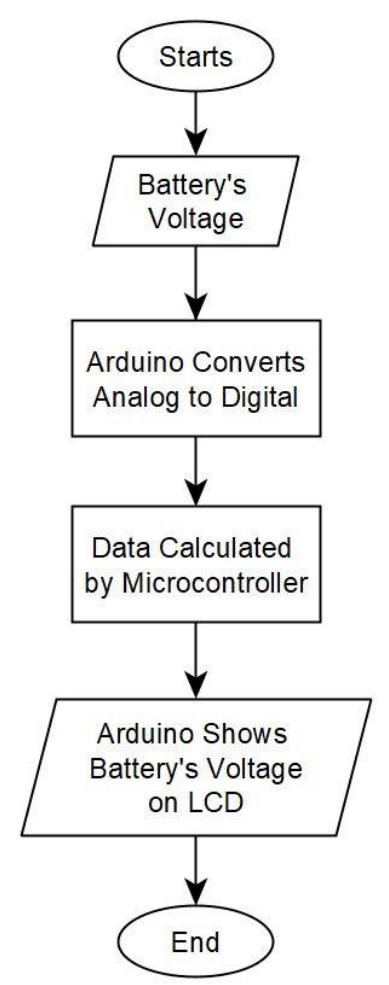

Figure 1. Working principle of the device

The explanation for Figure 1 is as follows:

1. The battery to be measured is plugged into the red probe (positive) and black probe (negative).

2. The voltage value is forwarded to the Arduino, the microcontroller on the Arduino converts the analog value to digital via the ADC (analog to digital converter) feature.

3. The digital signal is processed according to what is written in the Arduino sketch.

4. Arduino sends data to SDA and SCL pins on I2C LCD 16x02.

5. LCD displays data from Arduino

\section{Hardware Design}

Utilization of ADC pin on the Arduino nano is the most important thing in this research, considering that Arduino could only accept a maximum voltage of $5 \mathrm{~V}$ while the measured battery designed to a maximum voltage of $10 \mathrm{~V}$. If the battery voltage is directly connected to the Arduino then the Arduino can be damaged. Therefore, to overcome this problem, a voltage divider circuit is employed by using of two resistors. The circuit is as follows in figure 2 : 


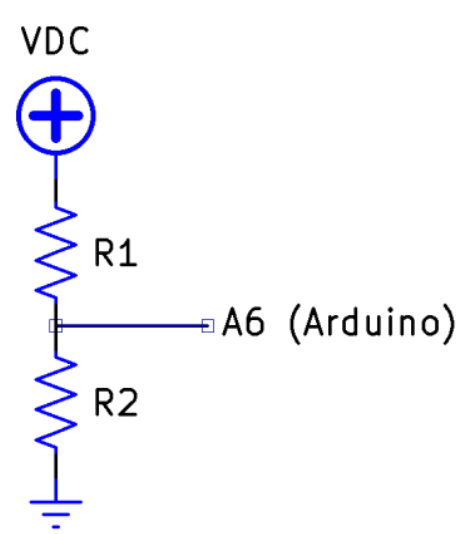

Figure 2. Voltage Divider Circuit

Based on Figure 2, if the input voltage is $10 \mathrm{~V}$, so the voltage enters $A 6$ pin is $5 \mathrm{~V}$ :

$$
\begin{gathered}
V_{D C}=V_{R 1}+V_{R 2} \\
10=I R_{1}+I R_{2} \\
I R_{1}=10-5=5 \\
I=\frac{5}{R_{1}}
\end{gathered}
$$

The current equation is substituted into equation 1:

$$
\begin{gathered}
10=\left(\frac{5}{R_{1}}\right) R_{1}+\left(\frac{5}{R_{1}}\right) R_{2} \\
10=5+5 \frac{R_{2}}{R_{1}} \\
5 \frac{R_{2}}{R_{1}}=5 \\
R_{1}=R_{2}
\end{gathered}
$$

Based on the equation 2, to make the input voltage $5 \mathrm{~V}$ to the Arduino, the values of $R_{1}$ and $R_{2}$ must be the same. In this study, two variations of resistors were used such a series arrangement of both $4.7 \mathrm{k} \Omega$ and $10 \mathrm{k} \Omega$ resistors. By employing all components needed, the schematics are made. The circuits of the device could be seen in Figure 3:

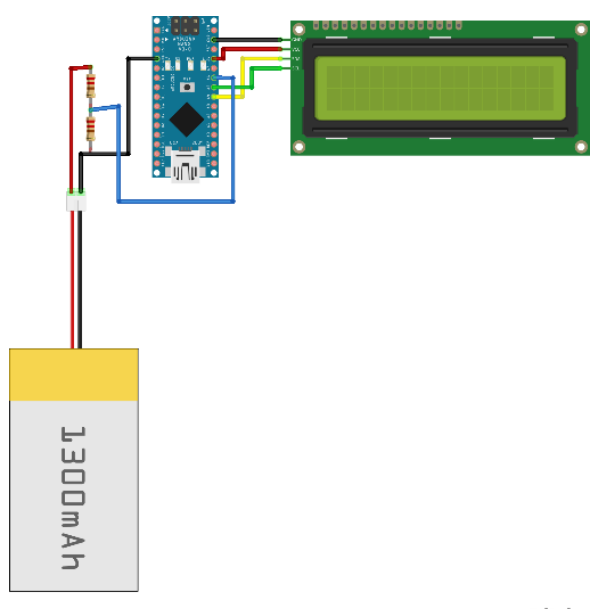

Figure 3. Battery voltmeter circuit

\section{Software Design}

ADC (Analog to Digital Converter) pin on the Arduino Nano is on $A 0$ to $A 7$ pins. If the input signal is an analog one, the signal is connected to $A D C$ pin so that it can be further processed by the microcontroller. In this study, A6 pin is used as input from the battery.

Arduino IDE is a software to write, compile and upload the code to the Arduino board. The code are written to instruct Arduino to process analog signals into digital then the digital signals are calculated and the results are displayed on the LCD screen. The coding for the device can be seen in the syntax below:

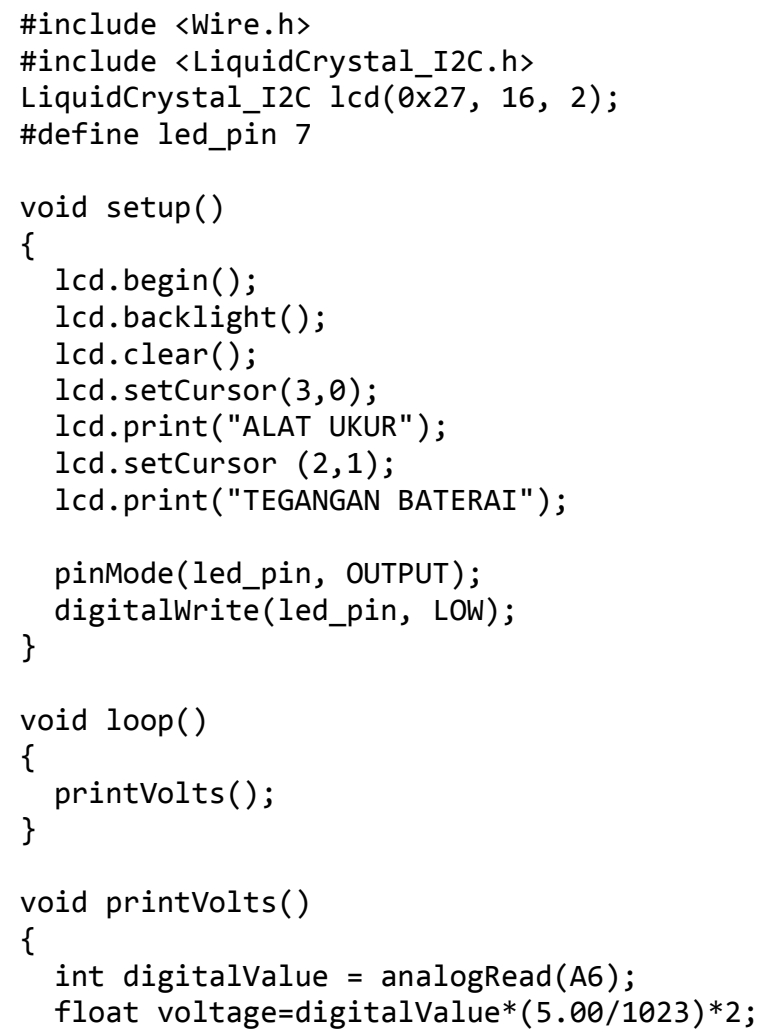


lcd. setCursor $(\theta, \theta)$;

lcd.print("Tegangan Baterai");

lcd. setCursor $(4,1)$;

lcd.print(voltage); \}

lcd.print (" V");

The syntax explanation can be seen in the following table:

Table 1. Explanation of the Syntax on ADC's work

\begin{tabular}{|c|c|}
\hline Syntax & Description \\
\hline $\begin{array}{l}\text { int digitalValue = } \\
\text { analogRead(A6); }\end{array}$ & $\begin{array}{l}\text { The analog signal is read from A6 pin } \\
\text { then converted to digital, the digital } \\
\text { value is assigned to the digitalValue } \\
\text { variable. The ADC pin on the Arduino } \\
\text { nano has a resolution of } 10 \text { bits, so the } \\
\text { decimal value is } 2^{9}=1023 \text {. } 1023 \text { is } \\
\text { equivalent to a voltage of } 5 \mathrm{~V} \text {. }\end{array}$ \\
\hline $\begin{array}{l}\text { float voltage = } \\
\text { digitalValue * } \\
(5.00 / 1023) * 2\end{array}$ & $\begin{array}{l}\text { If the analog value of digitalValue is at } \\
\text { the maximum value of } 5 \mathrm{~V} \text {, then the } \\
\text { digitalValue is } 1023 \text {. } 1023 \text { is multiplied } \\
\text { by } 5 \text { and divided by } 1023 \text {, the result is } \\
5 \text {. But the device designed to measure } \\
\text { maximum } 10 \mathrm{~V} \text {, so the concept of a } \\
\text { voltage divider is used. If the battery } \\
\text { voltage is } 10 \mathrm{~V} \text { then it goes } 10 / 2=5 \mathrm{~V} \text { to } \\
\text { A } 6 \text { pin. Therefore, voltage value shown } \\
\text { on LCD are the same value with } \\
\text { battery's voltage. }\end{array}$ \\
\hline
\end{tabular}

\section{Device Testing}

To find out whether the device performs properly or not, a comparison of the voltage reading between the device and a multimeter is carried out. The voltage source is a digital power supply whose voltage value can be varied. The device will be tested at a voltage of $0 \mathrm{~V}, 0.5 \mathrm{~V}, 1 \mathrm{~V}$ and so on until $10 \mathrm{~V}$.

\section{RESULTS AND DISCUSSION}

The device are in a development process so the prototype are shown in the figure 4 :

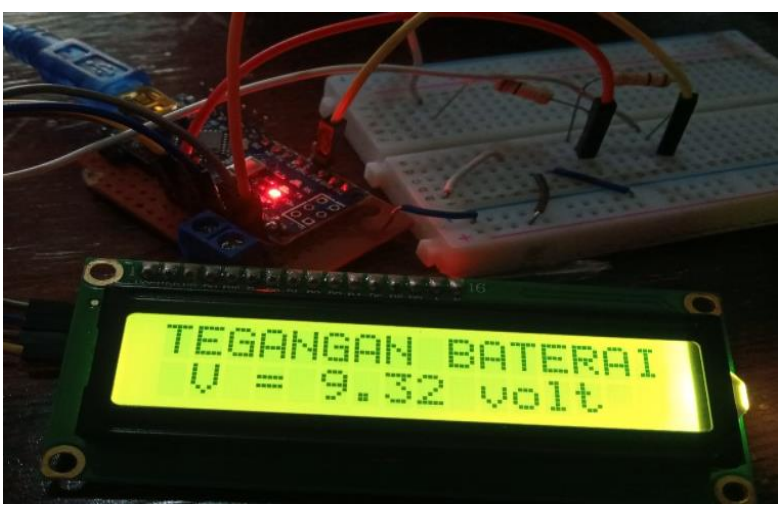

Figure 4. Schematics of battery-voltage meter
The data are collected by using both series $4.7 \mathrm{k} \Omega$ and $10 \mathrm{k} \Omega$ of resistors. Arduino's current input rating on $\mathrm{I} / \mathrm{O}$ pins is $40 \mathrm{~mA}$ [14]. By selecting series both $4.7 \mathrm{k} \Omega$ and $10 \mathrm{k} \Omega$ means that the current passing the A6 pin is $1.06 \mathrm{~mA}$ and $0.5 \mathrm{~mA}$ respectively. These currents are below $40 \mathrm{~mA}$ therefore it's could not damage the microcontroller. If the selected resistors below than $1 \mathrm{k} \Omega$ such as 220 ohm then the current pass through the A6 pin is $22.7 \mathrm{~mA}$. Even the smaller resistors produce current below $40 \mathrm{~mA}$ but it might affect the accuracy of ADC due to the normal current that operate in ADC pin is 120 to $195 \mu \mathrm{A}$ [15]. Therefore $4.7 \mathrm{k} \Omega$ and $10 \mathrm{k} \Omega$ are chosen. Explanation of them are follows:

\section{Series of $4,7 \mathrm{k} \Omega$ Resistors}

Schematics of voltage divider consists of two resistors, the output voltage are connected to A6 pin on Arduino nano. Current flows through Arduino is:

$$
V=I R_{\text {tot }}
$$

with $\mathrm{V}=10 \mathrm{~V}$ and $R_{\text {tot }}=4.7+4.7=9.4 \mathrm{k} \Omega$, then

$$
I=\frac{10}{9,4 \times 10^{3}}=1,06 \mathrm{~mA}
$$

Results of the device's measurement compared to voltage source are shown on the table 2:

Table 2. Device's reading compared to the voltage

\begin{tabular}{cc}
\multicolumn{3}{c}{ source } \\
\hline Voltage Source $(\mathrm{V})$ & Device's Reading $(\mathrm{V})$ \\
\hline 0 & 0 \\
0.5 & 0.54 \\
1 & 1 \\
1.5 & 1.54 \\
2 & 2.10 \\
2.5 & 2.56 \\
3 & 3.08 \\
3.5 & 3.54 \\
4 & 4.13 \\
4.5 & 4.65 \\
5 & 5.07 \\
5.5 & 5.56 \\
6 & 6.16 \\
6.5 & 6.61 \\
7 & 7.11 \\
7.5 & 7.62 \\
8 & 8.11 \\
8.5 & 8.64 \\
9 & 9.18 \\
9.5 & 9.63 \\
10 & 10 \\
\hline
\end{tabular}


Based on the table 2, average inaccuracy of device compared to voltage source is $0.09 \mathrm{~V}$. The result shows that resistor $4,7 \mathrm{k} \Omega$ not a good choice so it's replaced by $10 \mathrm{k}$ resistor.

\section{Series of 10k Resistors}

$4,7 \mathrm{k} \Omega$ resistors are replaced by $10 \mathrm{k}$ resistors, due to the higher value of $R$ the smaller current will flow. If value of $\mathrm{V}=10 \mathrm{~V}$ and $R_{\text {tot }}=10+10=20 \mathrm{k} \Omega$, current flows through Arduino is:

$$
I=\frac{10}{20 \times 10^{3}}=0,5 \mathrm{~mA}
$$

So the current passing series of $10 \mathrm{k} \Omega$ resistors is almost a half smaller than the previous one. To check the accuracy, device's measurement on voltage compared to voltage source are shown on the table 3 :

Table 3. Device's reading compared to the voltage

\begin{tabular}{cc}
\multicolumn{2}{c}{ source } \\
\hline Voltage Source $(\mathrm{V})$ & Device's Reading $(\mathrm{V})$ \\
\hline 0 & 0.51 \\
0.5 & 1.01 \\
1 & 1.54 \\
1.5 & 2.02 \\
2 & 2.52 \\
2.5 & 3.03 \\
3 & 3.51 \\
3.5 & 4.02 \\
4 & 4.54 \\
4.5 & 5 \\
5 & 5.52 \\
5.5 & 6.01 \\
6 & 6.54 \\
6.5 & 6.99 \\
7 & 7.53 \\
7.5 & 8.02 \\
8 & 8.5 \\
8.5 & 9 \\
9 & 9.47 \\
9.5 & 10 \\
10 &
\end{tabular}

Based on the table 3 , average difference between device's measurement and voltage source is $0.02 \mathrm{~V}$. the result shows that a series of $10 \mathrm{k} \Omega$ resistors has a better accuracy than the $4,7 \mathrm{k} \Omega$ resistors. Voltage's reading of the device is up to two digit after comma whereas a voltage source used in this experiment has one digit after comma, therefore the accuracy of the device is high. Current flowing through the voltage divider circuit affects the accuracy of the device.

\section{Digital Multimeter's Reading}

A digital multimeter is used to compare it's accuracy to a made-device, the multimeter is set to voltage scale and a voltage source is measured. The results shows on the table 4:

Table 4. Voltage Meter of a Digital Multimeter Voltage Source (V) Voltmeter (V)

\begin{tabular}{cc}
\hline 0 & 0 \\
0.5 & 0.46 \\
1 & 0.98 \\
1.5 & 1.43 \\
2 & 1.92 \\
2.5 & 2.40 \\
3 & 2.91 \\
3.5 & 3.44 \\
4 & 3.89 \\
4.5 & 4.36 \\
5 & 4.90 \\
5.5 & 5.39 \\
6 & 5.84 \\
6.5 & 6.36 \\
7 & 6.82 \\
7.5 & 7.29 \\
8 & 7.81 \\
8.5 & 8.32 \\
9 & 8.78 \\
9.5 & 9.30 \\
10 & 9.81 \\
\hline
\end{tabular}

Based on the table 4, digital multimeter's average reading is $0.12 \mathrm{~V}$ smaller compare to the source voltage. The result shows that the Arduinobased device for battery voltage-meter is more accurate than the digital multimeter's.

Comparison between device for battery voltage-meter and digital multimeter is shown in the figure 5 : 


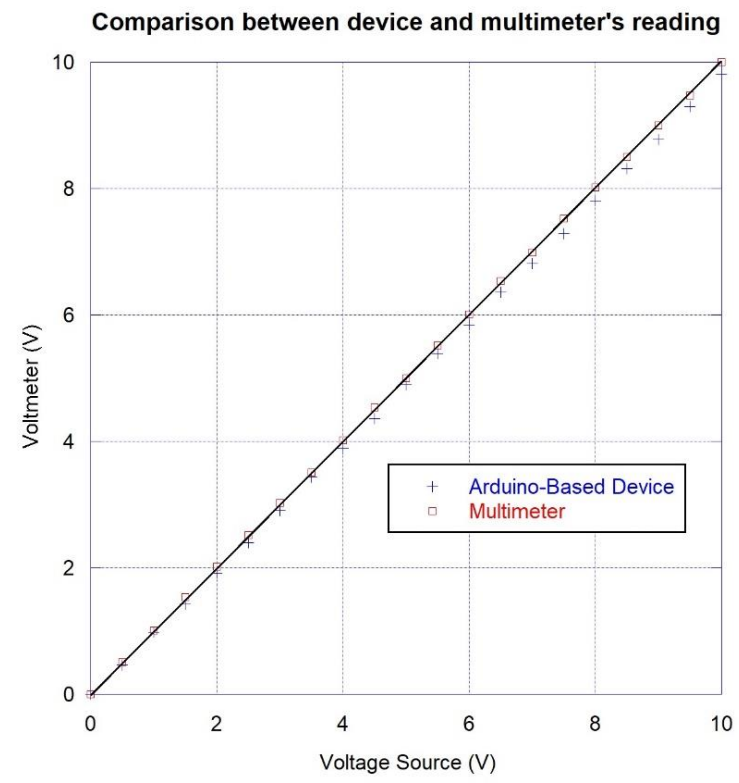

Figure 5. Accuracy's Comparison between Arduino-based Device and Multimeter

Based on figure 5, the dash line is the value of voltage source, $x$ sign for Arduino-based device and + sign for multimeter. The accuracy of the device is better than multimeter's so ADC pin on Arduino nano is accurate to measure voltage. Results on the testing stage indicates that the device is ready to measure any voltage of a battery with a high accuracy.

\section{Technical Specification of the Device}

By making calculation, observation and analyze the device performance, we summarized the technical specification of the device on table 5 :

\begin{tabular}{cc}
\multicolumn{2}{c}{ Table 5. Technical Specification of the device } \\
\hline Arduino-based Device & Value \\
\hline Measurement voltage & $0-10 \mathrm{~V}$ \\
Battery voltage & $0-10 \mathrm{~V}$ \\
Battery dimensions & AAA, AA and \\
& PP3 \\
Input voltage & $5 \mathrm{~V}$ \\
Power consumption & $0.2 \mathrm{w}$ \\
\hline
\end{tabular}

\section{CONCLUSION}

Arduino-based device could measure voltage source from 0 to $10 \mathrm{~V}$ therefore it's able to check any type and dimensions of battery. The device has a better accuracy when employs $10 \mathrm{k} \Omega$ series of resistors than the $4,7 \mathrm{k} \Omega$ resistors. The device could display the voltage value up to two digit after comma, the accuracy is better than a digital multimeter.

\section{REFERENCES}

[1] Y. A. Mahardika, "Perancangan Alat Indikator Tegangan pada Sistem Pengisian Sepeda Motor," 2017.

[2] M. Pauzan, "Rancangan Alat Indikator Level Tegangan Baterai Berbasis Operational Amplifier (Op Amp)," Teknokom, vol. 2, no. 1, pp. 2019, doi: 10.31943/teknokom.v2i1.26.

[3] N. Yahya and A. Ihlas, "Pemantau Tegangan Baterai Ion Litium dalam Rangkaian Empat Seri pada Aplikasi Penyimpan Energi Berdaya Tinggi," J. Pros. Semin. Nas. Tek. Kim., pp. 1-7, 2020.

[4] D. Satou, "Real-time Battery Cell Voltage Measurement Method Using LC Series Circuit Type Cell Voltage Equalizer," 2019 IEEE 4th Int. Futur. Energy Electron. Conf. IFEEC 2019, vol. 2, no. c, pp. 1-4, 2019, doi: 10.1109/IFEEC47410.2019.9015080.

[5] M. Pauzan and I. Yanti, "Penggunaan Pin ADC ( Analog to Digital Converter) pada Mikrokontroler ATmega8535 untuk Menghasilkan Catu Daya Digital," ELKHA J. Tek. Elektro Untan, vol. 11, no. 2, pp. 122127, 2019.

[6] M. Zlochisti, S. A. Zahrai, N. Le Dortz, and M. Onabajo, "Comparator design and calibration for flash ADCs within two-step ADC architectures," Proc. - IEEE Int. Symp. Circuits Syst., vol. 2019-May, 2019, doi: 10.1109/ISCAS.2019.8702523.

[7] L. A. Garcia-Lugo, E. C. Becerra-Alvarez, J. Ceballos-Caceres, and J. M. De La Rosa, "Using Arduino and on-chip serial-to-parallel register to test widely-programmable ADCs," 2016 Conf. Des. Circuits Integr. Syst. DCIS 2016 - Proc., pp. 125-128, 2017, doi: 10.1109/DCIS.2016.7845365.

[8] H. Wang, S. W. Sin, C. S. Lam, F. Maloberti, and R. P. Martins, "LDO-Free Power Management System: A 10-bit Pipelined ADC Directly Powered by Inductor-Based Boost Converter with Ripple Calibration," IEEE Trans. Circuits Syst. I Regul. Pap., vol. 67, no. 12, pp. 4174-4186, 2020, doi: 10.1109/TCSI.2020.3025350.

[9] T. Du, H. Geng, Y. Sun, H. Lin, H. Lv, and L. $\mathrm{Yu}$, "Design and implement of a low cost control system of active magnetic bearings using LabVIEW Interface for Arduino," 2017 IEEE Int. Conf. Mechatronics Autom. ICMA 2017, pp. 1833-1837, 2017, doi: 10.1109/ICMA.2017.8016096.

[10] N. Scharich, B. Schniter, A. Herbert, and M. S. Islam, "Battery management system using Arduino," 2017 IEEE Technol. Eng. Manag. Soc. Conf. TEMSCON 2017, pp. 384-387, 
2017

doi:

10.1109/TEMSCON.2017.7998405.

[11] H. A. Dharmawan, A. P. W. Yudi, and C. S. Widodo, "Timing management for acquisitions of AC voltage and current signals using an AVR microcontroller based system," Proc. - 2017 Int. Semin. Sensor, Instrumentation, Meas. Metrol. Innov. Adv. Compet. Nation, ISSIMM 2017, vol. 2017Janua, pp. 1-4, 2017, doi: 10.1109/ISSIMM.2017.8124250.

[12] K. El Hammoumi, R. El Bachtiri, M. Boussetta, and M. Khanfara, "Arduino Based Platform for Managing a PV Battery Charge," Proc. 2019 7th Int. Renew. Sustain. Energy Conf. IRSEC 2019, 2019, doi: 10.1109/IRSEC48032.2019.9078303.

[13] M. Senthilkumar, K. P. Suresh, T. Gunasekar, and C. Pazhanimuthu, "Efficient Battery Monitoring System for E-Vehicles," 2021 7th Int. Conf. Adv. Comput. Commun. Syst. ICACCS 2021, pp. 833-836, 2021, doi: 10.1109/ICACCS51430.2021.9442038.

[14] U. Manual, "Arduino Nano V2.3 User Manual," Arduino, pp. 1-5, 2008, [Online]. Available:

https://www.arduino.cc/en/Main/ArduinoBoar dUno.

[15] F. Reverter and M. Gasulla, "Experimental characterization of the energy consumption of adc embedded into microcontrollers operating in low power," I2MTC 2019 - 2019 IEEE Int. Instrum. Meas. Technol. Conf. Proc., vol. 2019-May, pp. 1-5, 2019, doi: 10.1109/I2MTC.2019.8826815. 